\title{
Faktor Pendukung dan Penghambat Penderita Diabetes Melitus dalam Melakukan Pemeriksaan Glukosa Darah
}

\author{
Rizana Fajrunni'mah, Diah Lestari, Angki Purwanti \\ Politeknik Kesehatan Kementerian Kesehatan Jakarta III, Bekasi, Indonesia
}

\begin{abstract}
Abstrak
Diabetes melitus (DM) adalah sekelompok gangguan metabolisme bersifat kronik yang ditandai peningkatan kadar glukosa darah serta gangguan metabolisme karbohidrat, lemak, dan protein. Setiap tahun lebih dari empat juta orang meninggal akibat DM dan jutaan orang mengalami efek buruk atau kondisi yang mengancam jiwa seperti serangan jantung, strok, gagal ginjal, kebutaan, dan amputasi. Kemampuan individu mengelola kehidupan seharihari serta mengendalikan dan mengurangi dampak penyakit yang dideritanya dikenal dengan self-management, yaitu mengikuti pola makan sehat, meningkatkan kegiatan jasmani, menggunakan obat DM dan obat pada keadaan khusus secara aman dan teratur, melakukan pemantauan kadar gula darah, serta perawatan kaki secara berkala. Beberapa penelitian melaporkan bahwa masih sedikit penderita DM melakukan pemantauan gula darah dengan baik. Penelitian ini bertujuan memperoleh pemahaman mendalam tentang pengalaman penderita DM dalam pemeriksaan kadar glukosa darah dengan menggunakan metode penelitian kualitatif pendekatan fenomenologi. Penelitian dilaksanakan pada bulan Juli-September 2016 di wilayah kerja Puskesmas Jatiwarna, Bekasi. Hasil analisis data teridentifikasi faktor pendukung pemeriksaan glukosa darah adalah faktor psikologis, sosial, edukasi, ekonomi, dan akses. Faktor penghambatnya adalah faktor psikologis, sosial, edukasi, penggunaan obat, sikap terhadap penyakit, dan persepsi terhadap jaminan kesehatan. Hasil penelitian diharapkan dapat menjadi masukan dalam meningkatkan kualitas edukasi dan pendampingan tenaga kesehatan kepada pasien sehingga pasien terbantu meningkatkan adaptasi dan kemampuannya memantau glukosa darah secara mandiri.
\end{abstract}

Kata kunci: Diabetes melitus, pemeriksaan glukosa darah

\section{Supporting and Inhibiting Factors of Diabetes Mellitus Patients in Performing Blood Glucose Examination}

\begin{abstract}
Diabetes mellitus (DM) is a chronic metabolic disorder marked by an increase in blood glucose levels and impaired metabolism of carbohydrates, fats, and proteins. Every year more than four million people die because diabetes and millions of people experience the ill effects of diabetes or life-threatening conditions such as heart attack, stroke, kidney failure, blindness, and amputation. The individual's ability to manage life, control and reduce the impact of the disease known as self-management is to follow a healthy diet, increasing physical activity, using the drug safely and regularly, monitoring blood sugar levels as well as maintenance feet regularly. Several studies reported only small number of DM patients examined blood glucose levels routinely. This study aim to gain a thorough understanding of individual experience with DM in examining blood glucose levels. This study used qualitative research with a phenomenological approach from July to September 2016 at Jatiwarna, Bekasi. The results identified factors supporting blood glucose examination were: psychological factors, social, educational, economic, and access to health care. The inhibiting factors were psychological factors, social, educational, drug use, attitudes toward the disease, and perceptions of health insurance. The results expected to improve the quality of education and mentoring for health workers. It will help patients improving the adaptability and the ability to blood glucose self-monitoring.
\end{abstract}

Key words: Blood glucose tests, diabetes mellitus 


\section{Pendahuluan}

Diabetes melitus (DM) merupakan sekelompok kelainan metabolik yang ditandai kenaikan kadar glukosa dalam darah atau hiperglikemia yang diakibatkan kekurangan sekresi insulin, gangguan metabolisme insulin, atau keduanya. ${ }^{1}$ Indonesia berada di posisi keempat penyumbang penderita DM terbesar dari jumlah total penderita DM di dunia setelah India yang menduduki peringkat pertama, lalu Cina yang menduduki peringkat kedua, dan Amerika Serikat di peringkat ketiga. Diperkirakan pada tahun 2030, jumlah penderita DM di Indonesia 21.257.000 jiwa. ${ }^{2}$ Hasil Riset Kesehatan Dasar pada tahun 2013 menunjukkan bahwa terjadi peningkatan prevalensi DM dari 1,1\% pada tahun 2007 menjadi 1,5\%. Di Provinsi Jawa Barat prevalensi penderita DM sebanyak $1,3 \%$.

Penderita DM dapat hidup normal dengan mengendalikan risiko terjadi komplikasi akibat DM. ${ }^{3}$ Menurut Konsensus Pengendalian dan Pencegahan DM Tipe 2 di Indonesia pada tahun 2011, perilaku sehat yang merepresentasikan self-management pada pasien DM antara lain mengikuti pola makan sehat, meningkatkan kegiatan jasmani, memakai obat DM dan obat pada keadaan khusus secara aman serta teratur, melakukan pemantauan kadar gula darah, dan melakukan perawatan kaki berkala. ${ }^{4}$ Pengelolaan DM bertujuan mengontrol kadar gula darah tetap dalam batas yang normal untuk mencegah komplikasi akut dan kronik. ${ }^{5}$ Fenomena yang terjadiadalah kurangnyakepatuhan penderita DM dalam mengontrol glukosa darahnya. Sebanyak 75\% pasien DM makan tidak sesuai anjuran dan $77 \%$ memantau serta menginterpretasikan gula darah secara keliru. ${ }^{6}$ Hanya 21,4\% penderita DM melakukan pemantauan gula darah dengan baik. ${ }^{7}$ Manajemen mandiri DM dalam aspek nutrisi dan terapi obat termasuk baik, namun tidak baik pada latihan fisik dan monitor kadar glukosa darah. $^{8}$ Penelitian lain menunjukkan hanya 25,5\% responden yang melakukan pemantauan gula darah dengan baik. ${ }^{9}$

\section{Metode}

Penelitian ini merupakan penelitian kualitatif dengan pendekatan fenomenologi. Partisipan dalam penelitian ini adalah enam penderita DM di wilayah kerja Puskesmas Jatiwarna Bekasi pada bulan Juli-September 2016. Pengambilan sampel dengan menggunakan metode purposive sampling. Data-data diambil melalui wawancara mendalam, kemudian dibuat transkrip verbatim. Data kemudian dianalisis dengan menggunakan metode thematic analysis.

Penelitian ini telah mendapatkan persetujuan dari Komite Etik Penelitian Politeknik Kesehatan Kementerian Kesehatan Jakarta III melalui surat Nomor: 056/KEPK-PKKJ3/05/2016.

\section{Hasil}

Penelitian ini melibatkan enam orang partisipan penderita DM, terdiri atas jenis kelamin laki-laki sebanyak tiga orang dan perempuan sebanyak tiga orang. Sebanyak dua orang berlatar pendidikan S-1, satu orang SMK, satu orang SMP, dan dua orang SD. Semua partisipan berstatus menikah. Terkait dengan pekerjaan, dua orang merupakan pensiunan dengan latar belakang profesi yang berbeda, satu orang karyawan swasta, satu orang wiraswasta, dan dua orang ibu rumah tangga. Usia rata-rata partisipan adalah 52 tahun yang termuda berusia 35 tahun dan yang tertua 71 tahun. Lima orang partisipan beragama Islam dan satu orang beragama Kristen. Dua orang partisipan bersuku Betawi, dua orang Sunda, satu orang Jawa, dan satu orang Batak.

Hasil penelitian ini didapatkan dua tema, yaitu faktor pendukung dan faktor penghambat pemeriksaan kadar glukosa dalam darah. Tiaptiap tema terdiri atas subtema yang merupakan analisis pernyataan partisipan. Berdasar atas pemaparan partisipan itu, faktor-faktor yang teridentifikasi sebagai pendukung pemantauan glukosa darah partisipan, yaitu faktor psikologis, sosial, edukasi, ekonomi, dan akses.

Faktor psikologis berperan dalam mendorong pemantauan kadar glukosa dalam darah terutama melalui faktor motivasi, kebiasaan, tujuan, serta kesadaran akan perubahan fisik yang dirasakan seperti pernyataan partisipan sebagai berikut:

"Yang penting itu, motivasinya ga pengen ngrepotin anak-anak. Udah... tapi itu memang harus disiplin...." (p.5)

"Lantaran gula saya tu kan udah tinggi gitu ya. Kan istilahnya apa ya takutnya penyakit gini-gini makanya saya cobalah kontrol juga. Kadang-kadang seminggu dua minggu sekalilah.”(p.6)

"Oh ya, nomer satu mungkin keluarga kali ya. Udah kebiasaan begitu dari kecil, apa seperti 
minum vitamin... itu rajin.”(p.5)

"Karena mau berangkat haji jadi saya menjaga dan periksa terus.”(p.4)

"Kalau badan udah ga enak, periksa. Kayak orang sakit, kayak mau flu, tapi bukan flu. Kebetulan kalau gula alarmnya ada di saya. Kerasa beda."(p.5)

Faktor sosial juga mempunyai peran dalam meningkatkan pemantauan kadar glukosa dalam darah. Faktor ini terutama melalui peran aktif dan dukungan keluarga terhadap partisipan, kedekatan hubungan dengan tenaga kesehatan, serta sharing group sesama penderita DM yang tercermin dalam pernyataan berikut:

"Ibu yang cerewet ngasih tau sebelum ke dokter. Nanti kalau udah dikasih tau ga boleh ini atau itu." (p.4)

"Pegawai puskesmas sama saya merhatiin kok. 'Suruh ke sini bapak', gitu mah sama saya, kalau sama yang lain mah ga tau (tertawa).”(p.3)

"Oh saudara yang bilang, beli alat itunya lho. Buat biar bisa ngecek, katanya gitu. Kalau ga ini biar dikirimin alatnya. Ga lah, beli sendiri aja."(p.5)

Faktor edukasi yang mendorong pemantauan glukosa darah hanya didapatkan dari satu orang partisipan melalui pernyataan berikut:

"Tu disuruh sama dokter, trus lapor sama dokter, katanya bagus ini. Ini teruskan aja pola hidupnya, obatnya juga. Jadi kita ngecek sendiri." (p.5)

Faktor ekonomi juga memberikan kontribusi dalam pemeriksaan glukosa darah. Beberapa partisipan menyatakan bahwa biaya pemeriksaan glukosa darah masih dapat ditanggung sesuai kemampuan mereka. Berikut pernyataannya:

"Akhirnya saya periksa di apotek itu cuma delapan ribu, padahal alatnya sama dengan puskesmas. Kita kan cari yang murah gitu." (p.4)

"Kebetulan saya pake biaya sendiri ya. Ga BPJS. Makanya saya bilang, orang-orang tu punya uang banyak, tapi kadang ga mau periksa, buat apa."(p.5)

Faktor terakhir yang teridentifikasi dalam mendorong pemeriksaan glukosa darah adalah faktor akses jarak terhadap tempat pemeriksaan dan akses terhadap penyedia alat pemeriksaan. Beberapa pernyataannya sebagai berikut:

"Kan ada ni di depan sini yang apotik rakyat." (p.6)

"Ini dapet alat yang baru, yang lama saya kasihin ke accu check, dapet ganti baru. Tanpa uang lho. Bagus itu... diganti yang baru. Baru gres itu." (p.5)

Dalam tema faktor penghambat pemeriksaan kadar glukosa di dalam darah terdapat enam subtema, yaitu faktor psikologis, sosial, edukasi, penggunaan obat, sikap terhadap penyakit, dan faktor persepsi terhadap jaminan kesehatan. Terdapat beberapa kesamaan label subtema ini dengan tema pendukung pemeriksaan glukosa darah sebelumnya, hal ini tidak dapat dihindari karena berdasar atas pengalaman partisipan masing-masing ditemui makna dan konteks yang berbeda dari satu label subtema yang sama.

Faktor psikologis tersebut merupakan faktor penghambat yang sangat dominan bagi beberapa partisipan dalam memeriksakan kadar glukosa darah mereka. Semua partisipan menyatakan bahwa mereka bermasalah terhadap kendali diri mereka sendiri, seperti malas, takut, trauma, kekhawatiran keakuratan alat, dan merasa sehat.

"Akhir-akhir ini saya kayak gimana ya. Jadi agak malas-malasan gitu ya. Nah itulah kadang-kadang saya gimana ya... (tertawa) bandel." (p.6)

"Saya pengen tau gula darah, cuma takut. Takutnya periksa lagibanyak lagipenyakitnya." (p.1)

"Pernah sampe empat ratus. Kok tinggi banget trus saya pantang ini itu. Badan abis, ga makan apa-apa, kurang gula. Lemes trus ambruk dibawa ke rumah sakit, berapa gula saya itu lima satu. Semenjak itu ga mantang apapun dimakan. Tapi ga periksa." (p.2)

"Ga tau akurat atau ga nya ga tau dah." (p.4) 
"Kemarin sempat lama tidak periksa. Oh ya, iya, iya karena merasa sehat.”(p.6)

Tema berikutnya untuk faktor penghambat pemeriksaan glukosa darah adalah faktor sosial, di antaranya tidak terdapat dukungan keluarga, tidak ada waktu untuk periksa, dan juga karena pekerjaan. Berikut pernyataan partisipan:

"Dukungan keluarga juga ga ada. Adik saya juga kena, tapi sama lillahi taala aja. Keluarga, anak-anak ga pernah ngomong apa-apa.”(р.2)

"Trus waktunya juga kan... kerja tiap hari kerja."(p.6)

"Lha kita emang kerjaannya ke puskes melulu... kan gitu." (p.4)

Faktor penghambat pemeriksaan glukosa darah yang paling penting juga di sini, yaitu faktor edukasi. Semua partisipan memiliki pengalaman terkait edukasi yang kurang adekuat sehingga menghambat dalam melakukan pemeriksaan glukosa darah.

"Sama itu tadi disuruh periksa hba1c ya? Tapi ga dijelasin itu apa, harus kapan periksanya. Itu kan tadi berhubung saya pengen ga makan obat lagi, trus disuruh periksa itu."(p.5)

"Karena feeling aja yang dirasakan, ga pernah dikasih penjelasan. Tergantung, suka-suka dokter. Waktu kemarin begitu konsul juga udah langsung kasih obat. Dalam hati saya pikir kok ga periksa dulu, gulanya berapa, apa ga takut salah obat, gitu kan... tapi dalam hati aja, ga saya ungkapin." (p.4)

"O ga ada saran begitu (kapan harus periksa gula darah). Ga ada begitu. Hanya bilang o tinggi gulanya." (p.6)

"Cuma saya juga ga bisa bilanginnya karena biasanya ibu-ibu kan bandel gitu kan katanya. Terserah ibu, gitu katanya. Tapi ga disuruh harus periksa kapan aja."(p.1)

Faktor penggunaan obat juga muncul dalam pernyataan seorang partisipan sebagai berikut:

"Tiap pagi minum glibenclamide tapi ga mantang makanan. Dan juga ga periksa.” (p.2)

Faktor sikap terhadap penyakit sebagai subtema dari faktor penghambat pemeriksaan kadar glukosa dalam darah. Berikut pernyataan partisipan:

"Saya nikmatin aja. Masalah umur lillahi ta'ala. Semua orang punya penyakit. Orang yang ga punya penyakitan juga tau-tau meninggal. Hidup untuk dinikmatin, jangan dibikin susah." (p.2)

Faktor persepsi terhadap jaminan kesehatan juga merupakan faktor yang didapatkan sebagai penghambat dalam pemeriksaan glukosa darah.

"Itu dua ribu empat belas deh kayaknya masih bayar, sebelum BPJS, padahal askes. Ya memang begitu, ketentuannya begitu. Udah kita ke askes, askes kan tiap bulan dipotong, udah gitu bayar lagi. Padahal saya dalam hati namanya puskesmas kan semuanya obatobatan didrop dari suku dinas, atau dinas lah, apa tenaga kan sudah dibayar dari PNS. Hanya terakhir-terakhir ini aja kita ga dimintain biaya, apa karena fasilitas haji atau gimana saya ga tau."(p.4)

"Saya tu percuma kadang istilahnya selama ini kita bayar-bayar BPJS. Tiap bulan kita kan bayar. Apalagi kita kan empat-empatnya bayar kelas dua. Jadi kita ibaratnya kan kalau lagi kena sakitnya kan baru pake. Gitu ya. Kadangkadang kita kalau ke sana mau periksa, kadang sakit apa." (p.6)

"Kalau BPJS tu banyak kecewanya. Untuk periksa, dapet resep aja lama.” (p.5)

\section{Pembahasan}

Komponen faktor psikologis yang dominan dirasakan oleh partisipan dalam melaksanakan pemeriksaankadarglukosa darah adalah motivasi, kebiasaan, tujuan, dan kesadaran atas perubahan fisik. Faktor motivasi diketahui berkorelasi positif dengan proses berubah, termasuk perubahan gaya hidup. Pada diabetes, motivasi diketahui akan meningkatkan kemampuan dan partisipasi pasien dalam manajemen glukosa darah secara mandiri. Pasien dengan tingkat motivasi yang baik terbukti mampu menyusun target yang harus dicapai dari perawatan, serta dapat melakukan tindakan-tindakan yang menunjang pencapaian target tersebut. ${ }^{10}$ Motivasi terdapat dua jenis, 
yaitu internal dan eksternal. Motivasi internal merupakan motivasi yang bersumber dari diri sendiri yang merupakan bawaan, sedangkan motivasi eksternal bersumber dari luar, seperti tujuan yang ingin dicapai. ${ }^{11}$ Motivasi internal yang didapatkan dari partisipan dapat diperoleh dari kebiasaan yang memang telah terbentuk dari kecil. Motivasi eksternal seperti tujuan akan bersifat tidak tetap karena akan menyesuaikan terhadap tujuan yang akan dicapai, misalnya partisipan melakukan pemantauan kadar glukosa dalam darah karena akan berangkat haji dan agar dapat menjalani operasi.

Kesadaran partisipan terhadap perubahan itu atau tanda-tanda fisik juga mempunyai peranan untuk mendukung pemeriksaan kadar glukosa darah seperti merasa ingin buang air kecil, mudah mengantuk dan lelah, serta badan terasa tidak enak. Penurunan kekuatan fisik dan mudah lelah merupakan perubahan yang dirasakan. Penyebab utama kelemahan fisik ini adalah uptake glukosa oleh sel sel tubuh berkurang. Jumlah insulin yang beredar rendah di dalam sistem sirkulasi tubuh serta resistensi insulin mengakibatkan sel tidak memperoleh asupan glukosa yang adekuat. Hal ini berakibat pada rendahnya produksi energi yang mempunyai manifestasi sebagai kelemahan fisik, mudah lelah, dan mengantuk. ${ }^{1}$

Faktor kedua yang mendorong pemeriksaan glukosa darah adalah faktor sosial yang meliputi dukungan keluarga, kedekatan hubungan dengan tenaga kesehatan, serta sharing group sesama penderita DM. Penelitian lain mengungkapkan bahwa faktor keluarga memiliki peranan penting dalam mendukung manajemen DM. Rendahnya konflik, baiknya kedekatan antara para anggota keluarga, serta komunikasi yang baik berperan dalam hal ini meningkatkan kepatuhan pasien. Dukungan sosial, terutama dari keluarga dan pasangan juga meningkatkan kepatuhan pasien terhadap program manajemen diabetes melitus. ${ }^{12}$ Dukungan keluarga merupakan salah satu faktor yang memengaruhi keteraturan kontrol kadar gula darah. ${ }^{13}$ Dukungan dari keluarga (dimensi emosional, penghargaan, instrumental, dan juga informasi) dengan kualitas hidup menunjukkan semakin tinggi nilai dukungan keluarga maka akan semakin tinggi nilai kualitas hidup pasien DM. ${ }^{14}$ Kedekatan hubungan antara pasien dan tenaga kesehatan merupakan salah satu faktor sosial yang didapatkan dari hasil wawancara dengan partisipan. Keadaan ini merupakan suatu bentuk dukungan yang diberikan oleh tenaga kesehatan kepada pasien. Hal ini juga pernah dinyatakan pada penelitian lain bahwa faktor yang memengaruhi keteraturan kontrol kadar gula darah adalah tingkat pendidikan, tingkat pengetahuan, waktu atau jarak tempuh, serta dukungan keluarga dan juga dukungan tenaga kesehatan. ${ }^{15}$

Sharing group sesama penderita DM juga merupakan faktor sosial yang dapat mendukung pemantauankadarglukosadarah. Halinitermasuk dukungan yang diberikan teman yang memiliki latar belakang penyakit yang sama. Dukungan sosial diartikan sebagai bantuan yang diterima dari orang lain yang memungkinkan untuk dapat mencapai kesejahteraan penerima dukungan. Sesuai dengan penelitian sebelumnya bahwa terdapat hubungan antara dukungan keluarga dan teman terhadap perilaku self management pada penderita DM khususnya dalam monitoring kadar glukosa darah. ${ }^{16}$ Dukungan sosial dapat bersumber dari pasangan, keluarga, juga tenaga kesehatan, maupun komunitas penyandang DM. Penelitian lain mengungkapkan bahwa dukungan sosial yang berasal dari kelompok penderita DM memiliki efek sama atau lebih baik dibanding dengan dukungan yang berasal dari istri atau teman yang tidak menderita DM. ${ }^{17}$

Faktor ketiga yang mendukung pemantauan kadar glukosa dalam darah adalah faktor edukasi. Hanya seorang partisipan yang mendapatkan edukasi yang baik dari tenaga kesehatan sehingga secara rutin memantau glukosa darah. Teori Green dalam Notoatmodjo (2014) menyatakan bahwa pengetahuan merupakan salah satu faktor pendukung (predisposing factor) terbentuknya perilaku pada seseorang. Penyandang DM perlu mendapatkan informasi minimal yang diberikan setelah diagnosis tersebut ditegakkan, mencakup pengetahuan dasar tentang DM, pemantauan secara mandiri, penyebab kadar glukosa darah yang tinggi, obat hipoglikemia oral, perencanaan makan (diet), perawatan, kegiatan jasmani, tanda hipoglikemia, dan juga komplikasi. Penyandang DM yang telah mempunyai pengetahuan cukup tentang DM, kemudian selanjutnya mengubah perilakunya sehingga akan dapat mengendalikan kondisi penyakitnya dan penyandang DM dapat hidup lebih berkualitas.

Faktor ekonomi merupakan faktor pendukung pemantauan kadar glukosa darah dalam hasil penelitian ini. Beberapa partisipan menyatakan kemampuan mereka untuk menanggung semua biaya pemeriksaan kadar glukosa darah karena 
masih terjangkau dengan kemampuan mereka tanpa diharuskan memanfaatkan kartu jaminan kesehatan yang mereka miliki. Menurut penelitian sebelumnya didapatkan bahwa penderita DM dengan kondisi ekonomi yang terbilang rendah melaksanakan upaya mengontrol dengan cara memanfaatkan kartu jaminan kesehatan dari pemerintah untuk mendapatkan pengobatan. Sebaliknya, untuk penderita DM dengan tingkat ekonomi mampu melakukan upaya mengontrol kesehatannya dengan pemeriksaan kesehatan secara rutin dan juga konsumsi makanan yang dapat dikontrol dengan leluasa. Dengan demikian, dapat disimpulkan bahwa terdapat hubungan kondisi ekonomi penderita DM dengan upaya yang dilakukan penderita DM untuk mengontrol kadar gula darah. ${ }^{18}$

Faktor terakhir yang mendukung pemantauan glukosa darah adalah akses terhadap pelayanan kesehatan. Akses itu yang cukup dekat dengan fasilitas kesehatan akan membuat partisipan melakukan pemantauan glukosa darah. Waktu dan juga jarak tempuh merupakan faktor yang memengaruhi keteraturan kontrol kadar gula darah. ${ }^{15}$ Pasien yang mempunyai tempat tinggal lebih dekat dengan fasilitas kesehatan tentunya akan lebih mudah untuk mengakses pelayanan kesehatan. Bagi partisipan yang telah mempunyai alat di rumah juga akan merasakan bahwa akses yang diberikan penyedia jasa alat pemeriksaan memberikan layanan yang memuaskan.

Faktor psikologis merupakan suatu hambatan yang cukup banyak dialami oleh partisipan. Hal ini merupakan kebalikan dari aspek psikologis dalam mendorong pemeriksaan glukosa darah. Hambatanyang ada adalah rasa malas yang berarti tidak ada motivasi di dalam diri maupun dari luar yang mendorong untuk melakukan pemantauan glukosa darahnya. Padahal motivasi itu sangat penting dalam hal mewujudkan suatu perilaku. Kondisi psikologis lainnya adalah takut terhadap hasil yang kemungkinan ditemukan atau kondisi penyakit-penyakit yang lain. Perasaan takut akan menghambat perilaku. Dalam studi Mitsonis dan Psarra $^{19}$ didapatkan hasil bahwa 40\% sampai dengan $42 \%$ responden mengalami peningkatan kecemasan ketika melakukan injeksi insulin dan saat mengecek kadar glukosa darahnya.

Rasa trauma yang diakibatkan pengalaman sebelumnya yang terjadi berkaitan dengan kondisi hipoglikemia juga menghambat pemeriksaan glukosa darah. Hal ini berimplikasi pada pola pengaturan glukosa darah partisipan yang lebih permisif gula darah tinggi karena merasa hal ini lebih baik untuk menghindari hipoglikemia. Efek negatifnya jelas, pasien akan cenderung mengalami hiperglikemia yang berkepanjangan dan konsekuensinya tentu akan meningkatkan risiko terhadap berbagai komplikasi DM baik akut maupun kronik. Keadaan ini patut menjadi perhatian bagi para tenaga kesehatan mengingat angka hipoglikemia di luar rumah sakit cukup tinggi, yakni mencapai lebih dari setengah dari pasien DM yang menjalani rawat jalan..$^{20}$ Banyak ditemui pasien DM dengan riwayat hipoglikemia secara sengaja membiarkan kadar glukosa dalam darah berada pada level di atas normal untuk menghindari hipoglikemia berulang. ${ }^{21}$

Rasa kekhawatiran terhadap keakuratan alat juga merupakan faktor penghambat pemantauan glukosa darah. Alat pemeriksaan memang sangat menentukan hasil yang diperoleh. Keakuratan alat tersebut seharusnya dipelihara oleh fasilitas pemeriksaan agar dapat dipercaya akan hasil yang didapatkan. Perasaan bahwa tubuhnya sehat dan tidak ada keluhan menyebabkan partisipan tidak memantau glukosa darahnya. Hal ini kurang tepat karena pemantauan glukosa darah penting untuk mengetahui apakah sasaran terapi telah tercapai dan untuk melakukan penyesuaian dosis obat bila belum tercapai sasaran terapi. ${ }^{5}$

Faktor sosial merupakan faktor kedua yang diidentifikasi berdasar hasil wawancara terhadap partisipan. Dukungan dari keluarga yang kurang menyebabkan tidak teratur melakukan kontrol gula darah. Tidak ada waktu karena bekerja juga merupakan faktor penghambat yang dikeluhkan pada hasil penelitian ini.

Faktor yang paling utama dalam menghambat pemantauan glukosa darah yang disampaikan partisipan adalah faktor edukasi yang diperoleh masih kurang adekuat. Informasi atau konseling yang kurang pada saat dilakukan pemeriksaan dapat menjadi salah satu faktor belum efektifnya proses pemeriksaan yang secara teratur terhadap pengaruhnya pada pengendalian kadar glukosa darah. Salah satu tujuan dianjurkan pemeriksaan teratur pada penderita DM adalah sebagai upaya deteksi dini terjadi komplikasi serta upaya penanganan klinis yang baik. ${ }^{22}$ Keempat pilar manajemen penatalaksanaan DM itu seharusnya disampaikan semua kepada pasien. Keberhasilan program manajemen DM tersebut secara mandiri ditentukan oleh kinerja dan peran aktif pasien serta keluarga, dan hal ini hanya dapat dicapai jika edukasi yang diberikan oleh tenaga kesehatan 
cukup efektif dalam mengubah dan memperbaiki kebiasaan serta perilaku pasien dan keluarga. ${ }^{23}$

Tujuan akhir edukasi itu adalah perubahan atau perbaikan perilaku, dengan demikian tenaga kesehatan perlu memahami bahwa perubahan perilaku memerlukan tahap tahap perubahan. Perubahan perilaku tidak dapat dicapai seketika, melainkan sedikit demi sedikit. ${ }^{23}$ Implikasinya adalah pemberi edukasi harus memiliki rencana dan kriteria evaluasi setiap kali dalam setiap interaksinya dengan pasien sehingga tahapan perubahan perilaku akan teridentifikasi secara objektif. ${ }^{21}$

Faktor penggunaan obat muncul dalam tema ini karena ada partisipan yang tetap menggunakan obat, namun tidak mau melakukan pemantauan kadar glukosa darahnya. Hal ini terbalik karena dengan pemantauan glukosa darah maka dapat diperoleh keberhasilan terapi. Bahkan jika hasil pemantauan baik, dapat jadi pasien hanya perlu melakukan gaya hidup sehat tanpa ditambah dengan penggunaan obat. Potensi bahan alami sebagai obat antidiabetes juga dapat digunakan seperti ekstrak kulit manggis dan tomat. ${ }^{24}$ Jus gel lidah buaya menghambat penyerapan glukosa di saluran cerna pada manusia. ${ }^{25}$ Ekstrak air labu kuning juga dapat menurunkan kadar glukosa darah puasa dengan bermakna. ${ }^{26}$

Sikap terhadap penyakit DM itu juga dapat menghambat melaksanakan pemantauan glukosa darah. Sikap penerimaan diri terhadap penyakit dan pasrah akan hidup yang dijalani membuat seorang partisipan tidak mau terlalu memikirkan penyakitnya sehingga juga tidak mau melakukan pemantauan glukosa darah.

Faktor terakhir yang berperanan menghambat pemantauan glukosa darah adalah persepsi yang kurang baik terhadap sistem jaminan kesehatan yangsudahada.Beberapapartisipanmengeluhkan mekanisme sistem jaminan kesehatan, misalnya tentang pembayaran dan fasilitas yang diterima kurang sesuai. Hal ini berkaitan dengan informasi yang didapatkan partisipan yang masih kurang. Menurut Peraturan Menteri Kesehatan Nomor 59 Tahun 2014 mengenai Standar Tarif Jaminan Kesehatan dinyatakan bahwa untuk pelayanan pemeriksaan penunjang rujuk balik di fasilitas kesehatan tingkat pertama meliputi pemeriksaan gula darah sewaktu, gula darah puasa (GDP), dan gula darah posprandial (GDPP). Pemeriksaan penunjang rujuk balik GDP dan GDPP dilakukan untuk 1 (satu) bulan 1 (satu) kali, sedangkan gula darah sewaktu dapat dilakukan sesuai dengan indikasi medis.

\section{Simpulan}

Faktor pendukung pemeriksaan kadar glukosa darah adalah faktor psikologis, sosial, edukasi, ekonomi, dan juga faktor akses. Hambatan yang ditemui partisipan dalam memeriksakan glukosa darah itu cukup kompleks, meliputi hambatan psikologis, sosial, edukasi, penggunaan obat, sikap terhadap penyakit, dan persepsi terhadap jaminan kesehatan.

\section{Ucapan Terima Kasih}

Ucapan terima kasih kepada Dinas Kesehatan Kota Bekasi, Badan Kesatuan Bangsa dan Politik Kota Bekasi, serta Kepala Puskesmas Jatiwarna Bekasi atas pemberian izin pengambilan data dan seluruh partisipan dalam memberikan data.

\section{Daftar Pustaka}

1. Maschak-Carey BJ. Assessment and management of patients with diabetes mellitus. Dalam: Smeltzer SC, Bare BG, Hinkle JL, Cheever KH, penyunting. Brunner \& Suddarth's textbook of medical-surgical nursing. Edisi ke-12. Philadelphia: Wolters Kluwer Health/Lippincott Williams \& Wilkins; 2010. hlm. 1196-244.

2. World Health Organization (WHO). Use of glycated haemoglobin (HbA1c) in the diagnosis of diabetes mellitus: abbreviated report of a WHO consultation. Geneva: WHO Press; 2011.

3. American Diabetes Association (ADA). Introduction. Diabetes Care. 2016;39(Suppl 1):S1-2.

4. Perkumpulan Endokrinologi Indonesia (Perkeni). Konsensus pengelolaan dan pencegahan diabetes melitus. Jakarta: PB Perkeni; 2011.

5. Shrivastava SR, Shrivastava PR, Ramasamy $\mathrm{J}$. Role of self-care in management of diabetes mellitus. J Diabetes Metab Disord. 2013;12(1):14.

6. Purba CIH, Sitorus R, Afiyanti Y. Pengalaman ketidakpatuhan pasien terhadap penatalaksanaan diabetes melitus: studi fenomenologi. JKI. 2008;12(2):84-90.

7. Mahfouz EM, Awadalla HI. Compliance to diabetes self-management in rural El- 
Mina, Egypt. Cent Eur J Public Health. 2011;19(1):35-41.

8. Mahmudin A. Evaluasi manajemen mandiri karyawan penyandang diabetes melitus tipe 2 setelah mendapatkan edukasi kesehatan di PT Indocement Tunggal Prakarsa Plantsite Citeureup (skripsi). Jakarta: Fakultas Ilmu Keperawatan Universitas Indonesia; 2012.

9. Putri DSR, Yudianto K, Kurniawan T. Perilaku self-management pasien diabetes melitus (DM). JKP. 2013;1(1);30-8.

10. BrittE. Enhancing diabetes self-management: motivational enhancement therapy (tesis). Canterbury: University of Canterbury; 2008.

11. Sarwono SW. Pengantar psikologi umum. Jakarta: Rajawali Press: 2009.

12. Delamater AM. Improving patient adherence. Clin Diabetes. 2006;24(2):71-7.

13. Priharianto A. Hubungan antara dukungan keluarga dengan keteraturan kontrol kadar gula darah pada penderita diabetes melitus di wilayah Puskesmas Bendosari Sukoharjo (skripsi). Surakarta: Fakultas Ilmu Kesehatan Universitas Muhammadiyah Surakarta; 2014.

14. Yusra A. Hubungan antara dukungan keluarga dengan kualitas hidup pasien diabetes melitus tipe 2 di Poliklinik Penyakit Dalam Rumah Sakit Umum Pusat Fatmawati Jakarta (tesis). Jakarta: Universitas Indonesia; 2011.

15. Albherta AY. Faktor yang mempengaruhi keteraturan kontrol kadar gula darah pada penderita diabetes melitus di Puskesmas Ketabang Surabaya (skripsi). Surabaya: Fakultas Kesehatan Masyarakat Universitas Airlangga: 2011.

16. Rosland AM, Kieffer E, Israel B, Cofield M, Palmisano G, Sinco B, dkk. When is social support important? The association of family support and professional support with specific diabetes self-management behaviors. J Gen Inter Med. 2008;23(12):1992-9.

17. van Dam HA, van der Horst FG, Knoops L, Ryckman RM, Crebolder HF, van den Borne
BH. Social support in diabetes: a systematic review of controlled intervention studies. Patient Educ Couns. 2005;59(1):1-12.

18. Cahyanto HN. Kajian tentang usaha penderita diabetes mellitus untuk mengontrol kadar gula darah di Desa Kedung Sukodani dan Desa Balongbendo, Kecamatan Balongbendo, Kabupaten Sidoarjo skripsi). Surabaya: Fakultas Ilmu Sosial dan Hukum, Universitas Negeri Surabaya; 2013.

19. Mitsonis C, Dimopoulos N, Psarra V. Clinical implications of anxiety in diabetes: a critical review of the evidence base. Eur Psychiatry. 2009;24(Suppl. 1):S526.

20. American Association of Clinical Endocrinologists (AACE). AACE 2011: survey reveals more than half of diabetes patients experience low blood sugar. Florida: AACE; 2011.

21. Dunning T. Care of people with diabetes: a manual of nursing practice. Edisi ke-3. West Sussex: Blackwell Publishing Ltd; 2009.

22. Putri NHK, Isfandiari MA. Hubungan empat pilar pengendalian dm tipe 2 dengan rerata kadar gula darah. JBE. 2013;1(2):234-43.

23. Wu SF. Effectiveness of self management for person with type 2 diabetes following the implementation of a self efficacy enhancing intervention program in Taiwan (disertasi). Queensland: Queensland University of Technology; 2007.

24. Yusni, Akbar IB, Rezania, Fahlevi R. Penurunankadargula darah akibatpemberian ekstrak manggis (Garcinia mangostana) dan tomat (Lycopersicum esculentum Mill) pada tikus diabetes. GMHC. 2017;5(1):57-63.

25. Jasaputra DK, Rahardja F, Christian E. Efek jus gel lidah buaya (Aloe vera L.) dalam menghambat penyerapan glukosa di saluran cerna pada manusia. GMHC. 2014;2(1):1-5.

26. Fathonah R, Indriyanti $A$, Kharisma $Y$. Labu kuning (Cucurbita moschata Durch.) untuk penurunan kadar glukosa darah puasa pada tikus model diabetik. GMHC. 2014;2(1):2733 . 